\title{
Procalcitonin in Children with Escherichia coli O157:H7 Associated Hemolytic Uremic Syndrome
}

\author{
HÉLÈNE DECALUWE, LISA M. HARRISON, MICHELE M. MARISCALCO, DOMINIQUE GENDREL, CLAUDE BOHUON, \\ VERNON L. TESH, AND FRANÇOIS PROULX
}

\begin{abstract}
Department of Pediatrics [H.D., F.P.], Intensive Care Medicine, Sainte-Justine Hospital, University of Montreal, Montreal, Quebec, Canada, H3T-1C5; Department of Pediatrics [M.M.M.], Leukocyte Biology and Critical Care Medicine, Baylor College of Medicine, Houston, Texas 77030; Department of Pediatrics and Clinical Biology [D.G., C.B.], Hopital Saint-Vincent-de-Paul, 75014 Paris, France; Department of Medical Microbiology and Immunology [L.M.H., V.L.T.], Texas A\&M University System Health Science Center, College Station, Texas 77843
\end{abstract}

\begin{abstract}
Shiga toxin producing Escherichia coli (STEC) are noninvasive enteric pathogens that may cause hemorrhagic colitis (HC) and diarrhea-associated hemolytic uremic syndrome (D+ HUS). We hypothesized that development of D+ HUS is associated with increased serum procalcitonin (PCT) levels. PCT was measured by an immunoluminometric assay in 113 patients. Concentrations of PCT were different in normal controls, disease control groups (rotavirus enteritis, HC due to non-STEC pathogens, chronic renal failure), and children with uncomplicated $\mathrm{O} 157: \mathrm{H} 7 \mathrm{HC}$ or D + HUS. Children with D + HUS showed higher PCT levels than those with uncomplicated $\mathrm{O} 157: \mathrm{H} 7 \mathrm{HC}$, and increased concentrations were noted in cases requiring peritoneal dialysis. Severely increased concentrations were observed in children with D + HUS on d 5 or 6 after the onset of enteritis, whereas serial measurements in those with uncomplicated $\mathrm{O} 157: \mathrm{H} 7 \mathrm{HC}$ remained within the normal range throughout the first week of illness. PCT was correlated with serum concentrations of lipopolysaccharide (LPS)-binding protein and serum levels of alanine aminotransferase. Using two separate sets of real-time PCR primers, we were unable to detect elevated PCT mRNA transcripts in nonadherent undifferentiated (monocytic) or differentiated (macrophage-like) THP-1 cells stimulated with purified Shiga toxin-1 and/or LPS. Our data show that serum levels of PCT are associated with the severity of illness in children with D+ HUS. Further studies are needed to determine the role of PCT in the pathogenesis of thrombotic microangiopathy associated to childhood D+ HUS. (Pediatr Res 59: 579-583, 2006)
\end{abstract}

D + HUS may occur after a prodrome of enteritis caused by STEC (1). STEC intimately adhere to intestinal epithelium, but, in contrast to Shigella, they do not invade the submucosae (2). Stxs have been detected on circulating neutrophils (3-6) and within kidneys of children with D+ HUS $(7,8)$. It has been proposed that after the translocation of Stxs across the intestinal epithelial barrier, the toxins may be

Received July 19, 2005; accepted November 9, 2005

Correspondence: François Proulx, M.D., Department of Pediatrics, Sainte-Justine Hospital, 3175 Chemin Côte Sainte-Catherine, Montreal (Quebec), Canada, H3T-1C5; e-mail: fproulx_01@yahoo.ca

This study was presented in part at the 12th International Congress of Immunology and 4th Annual Conference of FOCIS, Montreal, July 20, 2004.

This study was supported by the Fonds de Recherche clinique from Ste-Justine Hospital (F.P.) and U.S. Public Health Service Grant 2RO1 AI34530-10 from the National Institutes of Health (V.L.T.).

DOI: 10.1203/01.pdr.0000203100.45658.d5 disseminated through a neutrophil "piggy-back" mechanism, resulting in the development of systemic microvascular injury (2). However, many aspects of the pathogenesis of childhood D+ HUS remain unclear. Data from animal models suggest that LPS or proinflammatory cytokines such as tumor necrosis factor (TNF)- $\alpha$ are cofactors with Stxs in the genesis of thrombotic microangiopathy within renal glomeruli (2). In support of this supposition, Stxs and LPS have been shown to induce the expression of soluble cytokines by human monocytes in vitro (9), and the depletion of liver and splenic macrophages in mice decreased Stx lethality (10).

In response to infection, the calcitonin I gene is activated leading to the synthesis of calcitonin precursors, including PCT, which is subsequently processed into calcitonin. Increased serum PCT levels have been noted in baboons or healthy adult volunteers treated with LPS $(11,12)$. The serum half-life of PCT is approximately $24 \mathrm{~h}$, which is longer than the proinflammatory cytokines TNF- $\alpha$ or IL-6 (12-14). Low concentrations of PCT are found in patients with noninfectious inflammatory processes $(<1.0-2.0 \mu \mathrm{g} / \mathrm{L})$ or viral infections $(<0.5-1.0 \mu \mathrm{g} / \mathrm{L})$. Indeed, interferon- $\gamma$ inhibits IL- $1 \beta-$ induced calcitonin mRNA expression (15). Conversely, massive serum PCT elevations have been reported after administration of pan-T cell antibodies $(16,17)$.

We hypothesized that development of D+ HUS is associated with increased serum PCT levels. We compared serum PCT concentrations in children with D + HUS, those with uncomplicated E. coli O157:H7 HC, disease control groups, and normal controls. We then stimulated undifferentiated (monocytic) or differentiated (macrophage-like) THP-1 cells with purified Stx-1 and/or LPS to examine PCT mRNA expression by real-time polymerase PCR.

Abbreviations: ALT, alanine aminotransferase; CRF, chronic renal failure; D+ HUS, diarrhea-associated hemolytic uremic syndrome; HC, hemorrhagic colitis; LPS, lipopolysaccharide; PBMC, peripheral blood mononuclear cell; PCT, procalcitonin; Stxs, Shiga toxins; STEC, Shiga toxin producing Escherichia coli 


\section{METHODS}

Clinical data. From April 1, 1996, to March 1, 2002, children aged $<18$ y old who presented at Sainte-Justine Hospital with E. coli O157:H7 HC or $\mathrm{D}+$ HUS were eligible for the study. This cohort has been, in part, previously characterized by our group (18). Enteritis was defined as the acute onset of watery diarrhea ( $>1 \mathrm{~d}$ ) with or without abdominal pain. $\mathrm{HC}$ was defined as an enteritis followed by grossly visible bloody stools before medical consultation. D+ HUS was defined as a prodrome of enteritis or $\mathrm{HC}$ with 1) thrombocytopenia $(<150,000$ cells/L); 2) microangiopathic hemolytic anemia ( $\mathrm{Hb}$ below the third percentile for age- and sex-matched controls) with fragmented red cells on blood smear; and 3) acute renal failure (serum creatinine values over the 97 th percentile for age) (19). Age, sex, date of onset of enteritis, and occurrence of HUS were noted. Results of stool cultures, complete blood count, and serum ALT levels were recorded. Charts were also reviewed for evidence of nosocomial infections. Among patients with $\mathrm{D}+$ HUS, blood samples were obtained before starting peritoneal dialysis if needed. The normal control (NC) group included age- and sex-matched patients undergoing elective surgery for inguinal hernia or strabismus. A disease control group was composed of patients admitted to a general pediatric ward with rotavirus enteritis and negative bacterial stool cultures. Children with HC due to non-STEC pathogens (Salmonella, $n=4$; Yersinia, $n=1$; Campylobacter, $n=5$; negative culture, $n=5$ ) were also included. The disease control group for renal failure was composed of nine children on chronic ambulatory peritoneal dialysis with chronic renal failure (CRF) due to reflux nephropathy $(n=4)$, renal dysplasia $(n=2)$, glomerulonephritis $(n=$ 2 ), and nephrosis $(n=1)$. In this group, the median serum creatinine was 390 $\mu \mathrm{M}$ (range, 118-1000 $\mu \mathrm{M}$ ). They presented no signs of upper respiratory tract infections and had normal temperatures as well as negative urine and dialysate cultures before obtaining blood samples.

Laboratory data. Sorbitol-negative colonies grown on MacConkey-sorbitol agar were subcultured onto blood agar and screened for E. coli serotype $\mathrm{O} 157$ by slide agglutination (Difco, Detroit, MI). Colonies agglutinating with the antiserum were identified as E. coli by standard biochemical reactions. Identification of pathogen was available within 24-48 $\mathrm{h}$ of sample collection. Evidence of rotavirus enteritis was obtained by an ELISA (Pathfinder Rotavirus, Bio-Rad Laboratories, Redmond, WA). Blood samples were collected, allowed to clot, and centrifuged for $10 \mathrm{~min}$ at $4^{\circ} \mathrm{C}$ and $3000 \mathrm{~g}$. Specimens were aliquoted and stored at $-80^{\circ} \mathrm{C}$ until assayed. Serum PCT was determined by a blind immunoluminometric assay, using two MAb directed against the calcitonin and katacalcin sequences of procalcitonin (BRAHMS PCT-LIA or LUMItest PCT, BRAHMS, Hennigsdorf, Germany). The variability of the assay was 3-6\%. The lower detection limit of the assay was $0.1 \mu \mathrm{g} / \mathrm{L}$. Values higher than $0.5-1.0 \mu \mathrm{g} / \mathrm{L}$ are usually considered abnormal.

Analysis of PCT mRNA expression by real-time PCR The undifferentiated human myelogenous leukemia cell line THP-1 was maintained in RPMI 1640 supplemented with Pen/Strep and 10\% fetal bovine serum at $37^{\circ} \mathrm{C}$ in $5 \% \mathrm{CO}_{2}$. Approximately $5 \times 10^{5}$ cells in $500 \mu \mathrm{L}$ medium were plated in 12-well cell culture plates and treated with medium alone, purified Stx-1 (400 ng/mL), purified E. coli O111:B4 LPS (200 ng/mL; Sigma Chemical Co., St. Louis, MO) or both for $0,1,2,4,6$, and $8 \mathrm{~h}$. To differentiate cells to the mature macrophage-like state, approximately $1 \times 10^{6}$ cells $/ \mathrm{mL}$ were plated in 12-well cell culture plates in the presence of $50 \mathrm{ng} / \mathrm{mL}$ phorbol 12 -myristate 13-acetate for $48 \mathrm{~h}$. Approximately $50 \%$ of cells will adhere to the plate. Cells were washed twice with cold, sterile PBS and fresh RPMI $1640+$ fetal bovine serum were added. The medium was replaced daily, until the fourth day, when the experiments were conducted using the same experimental conditions as for undifferentiated cells.

Total RNA from each sample was extracted using the QIAgen QIAshredder and RNeasy Mini Kit (QIAGEN, Valencia, CA) protocols with the added DNase treatment. RNA was eluted using $50 \mu \mathrm{L}$ RNase/DNase-free water (Invitrogen, Carlsbad, CA). RNA was reverse transcribed using TaqMan reagents and real-time PCR performed using SYBR Green I double-stranded DNA binding dye (Applied Biosystems, Foster City, CA). PCT mRNA was measured using primers sets derived from NCBI Sequence Viewer (BC069704):

Set 1: Procalcitonin-F TTCCTGGCTCTCAGCATCTTG

Procalcitonin-R CAGACCTGAATGGTGCTGCAT

Set 2: Procalcitonin-F2 TCTAAGCGGTGCGGTAATCTG

Procalcitonin-R2 CTTGTTGAAGTCCTGCGTGTATG

The first set of primers was derived from the $5^{\prime}$ end of the procalcitonin cDNA, whereas the second set of primers targeted the middle portion of the cDNA. Real-time PCR were done on undifferentiated (monocyte-like) and differentiated (macrophage-like) THP-1 cells with or without stimulation by Stx1 and/or LPS. Positive controls using primers amplifying GADPH were carried out (20). Reactions were run and analyzed with the ABI PRISM 7500 sequence detection system (Applied Biosystems) using reaction parameters previously described (9).

Ethics. Written informed consent was obtained from the parents of all children. The study was approved by the Ethics Committee of Sainte-Justine Hospital.

Statistics. Descriptive statistics are presented as mean \pm SD for data with a normal distribution; median and range were used otherwise. The $t$ test was used to compare continuous data with a normal distribution and the MannWhitney $U$ test was used when the distribution was abnormal. The KruskalWallis test $(\alpha=0.05$ ) was used to compare age, $\Delta$ time between onset of enteritis and blood sample collection, leukocyte count, and serum levels of PCT among the following independent groups: 1) normal controls; 2) disease controls with rotavirus enteritis; 3) patients with HC caused by non-STEC pathogens; 4) children with uncomplicated $E$. coli $\mathrm{O} 157: \mathrm{H7}$ HC; 5) D+ HUS; and 6) disease controls with CRF unrelated to STEC infection. Orthogonal, 2 $\times 2$ comparisons were then performed using the test of Dunn $(\alpha=0.0033)$. All statistical tests were two-sided. We performed linear regression analysis between concentrations of PCT, and age, time after the onset of enteritis, leukocyte counts, $\mathrm{Hb}$ levels, platelet counts, serum urea, creatinine, ALT levels, and inflammatory mediators $(18,21-24)$, including LPS-binding protein (25).

\section{RESULTS}

We recruited 113 patients, among whom 154 blood samples were analyzed. Stool cultures showed evidence of E. coli O157:H7 in 79\% (26/33) of children with D+ HUS. As listed in Table 1, the sex distribution was comparable between groups. Children with CRF were older than any other group $(p<0.0001)$. Those with rotavirus enteritis were younger

Table 1. Clinical characteristics of patients

\begin{tabular}{|c|c|c|c|c|c|c|c|}
\hline & $\begin{array}{c}\mathrm{NC} \\
(n=22)\end{array}$ & $\begin{array}{l}\text { VIRAL GE } \\
(n=11)\end{array}$ & $\begin{array}{c}\text { NON O157 HC } \\
\quad(n=15)\end{array}$ & $\begin{array}{c}\mathrm{O} 157: \mathrm{H} 7 \mathrm{HC} \\
(n=23)\end{array}$ & $\begin{array}{l}\mathrm{D}+\mathrm{HUS} \\
(n=33)\end{array}$ & $\begin{array}{c}\text { CRF } \\
(n=9)\end{array}$ & \\
\hline \multicolumn{8}{|l|}{ Sex } \\
\hline$(\mathrm{M} / \mathrm{F})$ & $14: 8$ & $8: 3$ & $10: 5$ & 9:14 & $18: 15$ & $4: 5$ & NS \\
\hline $\begin{array}{l}\text { Age } \\
\text { (Mo) }\end{array}$ & $\begin{array}{c}50 \\
(29-217\end{array}$ & $\begin{array}{c}14 \\
(8-56)\end{array}$ & $\begin{array}{c}46 \\
(10-152)\end{array}$ & $\begin{array}{c}66 \\
(12-172)\end{array}$ & $\begin{array}{c}28 \\
(5-200)\end{array}$ & $\begin{array}{c}156 \\
(72-222)\end{array}$ & $<.0 .0001 \dagger$ \\
\hline $\begin{array}{l}\Delta \text { Time* } \\
\text { (days) }\end{array}$ & - & $\begin{array}{c}3 \\
(1-4)\end{array}$ & $\begin{array}{c}4 \\
(0-10)\end{array}$ & $\begin{array}{c}3 \\
(1-12)\end{array}$ & $\begin{array}{c}7 \\
(0-44)\end{array}$ & - & $<0.0001 \ddagger$ \\
\hline $\begin{array}{l}\text { WBC } \\
\left(\times 10^{9} / \mathrm{L}\right)\end{array}$ & - & $\begin{array}{c}8.6 \\
(5.2-17.9)\end{array}$ & $\begin{array}{c}8.4 \\
(5.6-15.3)\end{array}$ & $\begin{array}{c}9.0 \\
(1.7-19.4)\end{array}$ & $\begin{array}{c}17.8 \\
(11.4-39.7)\end{array}$ & - & $<0.001 \S$ \\
\hline
\end{tabular}

Normal controls (NC); Gastroenteritis (GE); Hemorrhagic colitis (HC); Diarrhea associated hemolytic uremic syndrome (D+ HUS); Chronic renal failure (CRF); Male (M)/Female (F); Months (Mo); White blood cell count (WBC). Values are expressed as median (range).

* Time between the onset of enteritis and blood sample collection.

$\dagger$ CRF vs any other group, $p<0.0001$; viral GE vs O157:H7 HC, $p<0.002$.

$\ddagger$ HUS vs any other group, $p<0.001$.

$\S$ HUS vs O157:H7 HC, $p<0.002$. 
than patients with uncomplicated O157:H7 HC $(p<0.002)$. Children with D+ HUS showed a longer time interval between the onset of enteritis and that of blood sampling ( $p<$ $0.001)$, as well as higher white blood counts $(p<0.001)$.

Serial measurements of serum PCT levels among nine children with uncomplicated E. coli $\mathrm{O} 157: \mathrm{H} 7 \mathrm{HC}$ are presented in Figure 1, which shows that PCT concentrations remained within the normal range from the onset of enteritis throughout the first week of the disease. PCT levels among children with STEC infections and control groups are shown in Figure 2. These were significantly different between groups $(p<0.0004)$. Children with D+ HUS presented higher PCT concentrations than those with uncomplicated $\mathrm{O} 157: \mathrm{H} 7 \mathrm{HC}$ $(p<0.002)$. Serum PCT levels were also increased in children with D+ HUS who required dialysis: $(n=9)$ dialyzed, 2.3 $(0.2-125)$ versus $(n=24)$ nondialyzed, $0.4(0.2-1.8) ; p<$ 0.003 . Concentrations of PCT were not correlated to any of the following parameters: age, $\Delta$ time, $\mathrm{Hb}$ levels, platelet and total leukocyte counts. PCT was weakly associated to the neutrophil count $\left(R^{2}=0.1 ; p<0.01\right)$ and serum creatinine levels $\left(R^{2}=0.2 ; p<0.006\right)$. PCT levels are shown as a function of time after the onset of enteritis in Figure 3.

Severely increased PCT levels were noted in four patients with HUS on d 5 and 6 of enteritis $(8,13,59,125 \mu \mathrm{g} / \mathrm{L})$. One child had acute pancreatitis and presented with hallucinations $(59 \mu \mathrm{g} / \mathrm{L})$, whereas another presented with convulsions and had particularly severe colitis $(125 \mu \mathrm{g} / \mathrm{L})$. There was no evidence of nosocomial infections. Children with O157:H7 HC had PCT concentrations within the normal range, except for one measurement $(1.9 \mu \mathrm{g} / \mathrm{L})$ obtained on d 3. As PCT is an acute phase reactant, its relationship with ALT concentrations was evaluated for the whole study population. Figure 4 shows that most patients with increased serum PCT presented 2- to

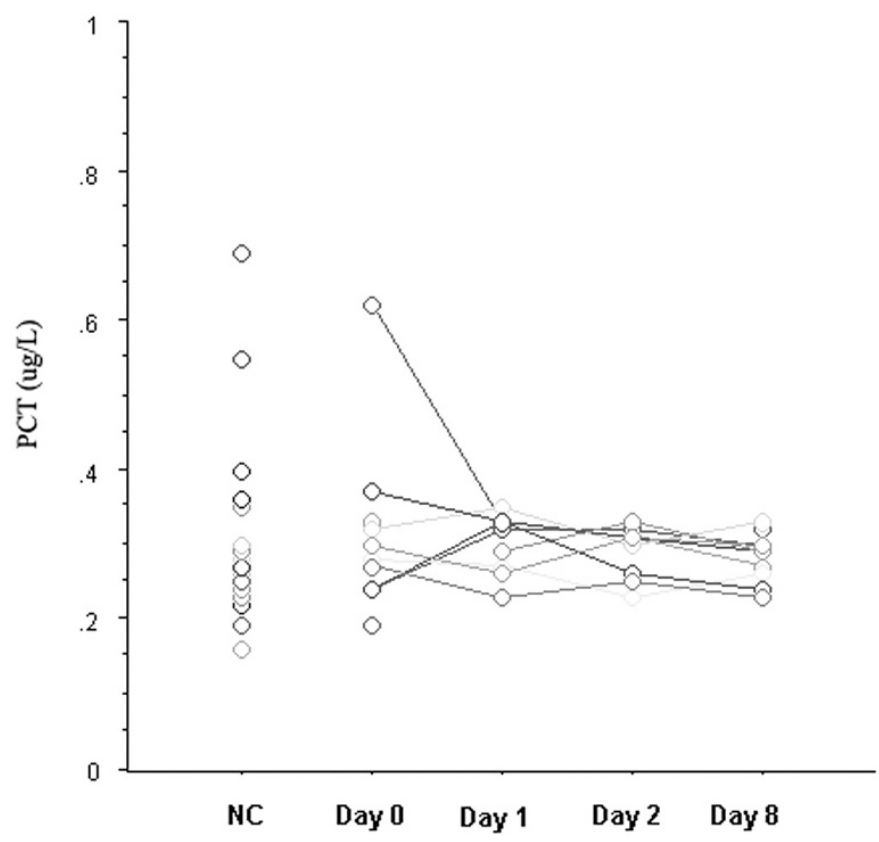

Figure 1. Circulating levels of PCT among children with uncomplicated E. coli $\mathrm{O} 157: \mathrm{H7}$ HC. Serial measurements performed on d 0, 1, 2, and 8 after the onset of enteritis $(n=9)$ were within those noted among normal controls $(N C, n=22, \mathrm{NS})$.

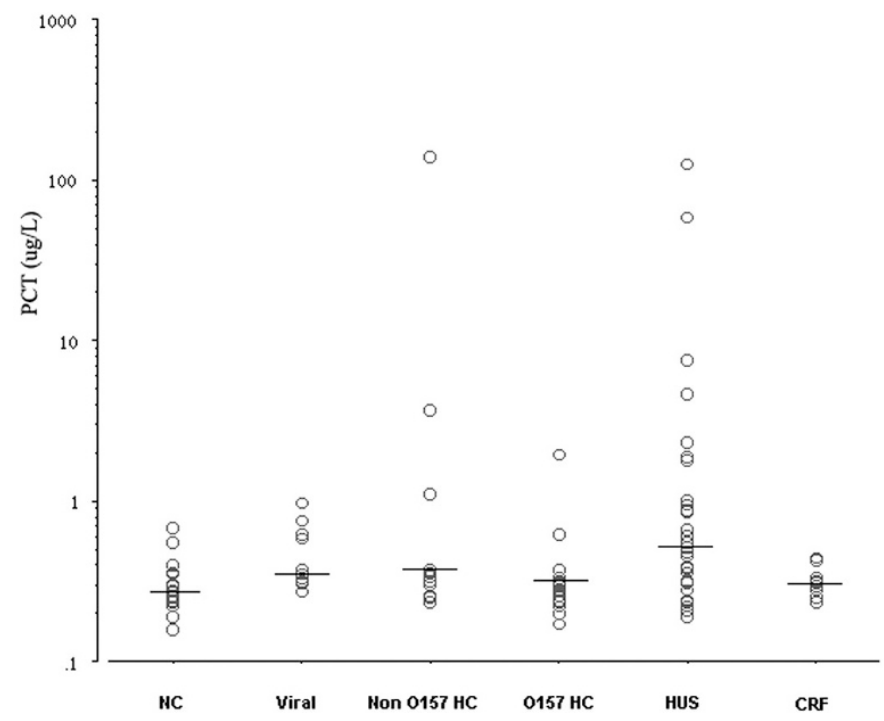

Figure 2. Circulating levels of PCT among children with E. coli O157:H7 infections and control groups. Median concentrations $(-)$ were different between groups $(p<0.0004)$ : $\mathrm{NC}(n=22), 0.3(0.2-0.7)$; viral $(n=11), 0.4$ (0.3-1.0); non-O157 HC $(n=15), 0.3(0.2-140)$; uncomplicated $E$. coli O157:H7 HC $(n=23), 0.3(0.2-1.9)$; D+HUS $(n=33), 0.5(0.2-125)$; CRF $(n=9), 0.3(0.2-0.4) \mu \mathrm{g} / \mathrm{L}$. Increased PCT levels were noted among children with D+ HUS compared with those with uncomplicated O157:H7 HC (6.5 \pm 23.6 vs $0.4 \pm 0.4 \mu \mathrm{g} / \mathrm{L} ; p<0.002)$.

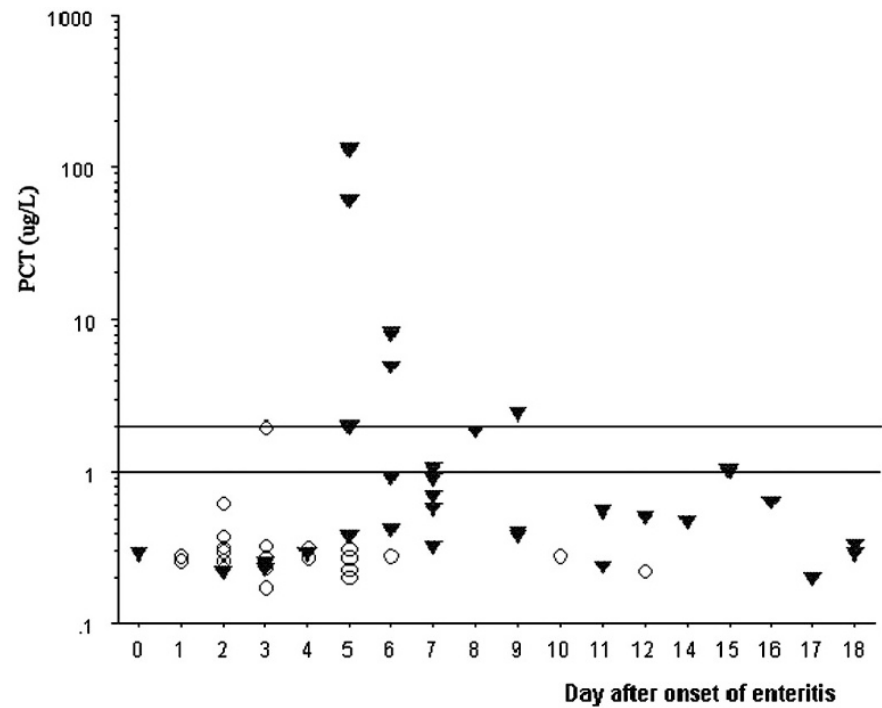

Figure 3. Circulating levels of PCT according to the time of onset of enteritis. Children with uncomplicated E. coli $\mathrm{O} 157: \mathrm{H} 7 \mathrm{HC}(\bigcirc)$, and those with diarrhea associated hemolytic uremic syndrome $(\nabla)$. Values $>1.0 \mu \mathrm{g} / \mathrm{L}$ are usually considered abnormal (first horizontal line). PCT levels $>2 \mu \mathrm{g} / \mathrm{L}$ were noted in children with D+ HUS (second horizontal line). Four children with hemolytic uremic syndrome presented severely increased PCT levels on d 5 or 6 after the onset of enteritis $(8,13,59,125 \mu \mathrm{g} / \mathrm{L})$. Elevated concentrations were also noted in two children with Salmonella infection: $140 \mu \mathrm{g} / \mathrm{L}$ on first day of illness and $4 \mu \mathrm{g} / \mathrm{L}$ on $\mathrm{d} 4$ (data not shown).

5-fold increased ALT levels. Finally, we noted that PCT was correlated with LPS-binding protein $\left(n=22, R^{2}=0.6 ; p<\right.$ $0.0001)$ (25), but not other inflammatory mediators previously studied by us: $\left(n=25-50, R^{2}<0.1, p=\mathrm{NS}\right.$, for: TNF- $\alpha$, IL-1 $\beta$, IL1-receptor antagonist, IFN- $\gamma$, IL-6, IL-8, IL-10, selectins-L, -P, -E, intercellular adhesion molecule-1, vascular cell adhesion molecule-1, granulocyte colony-stimulating fac- 


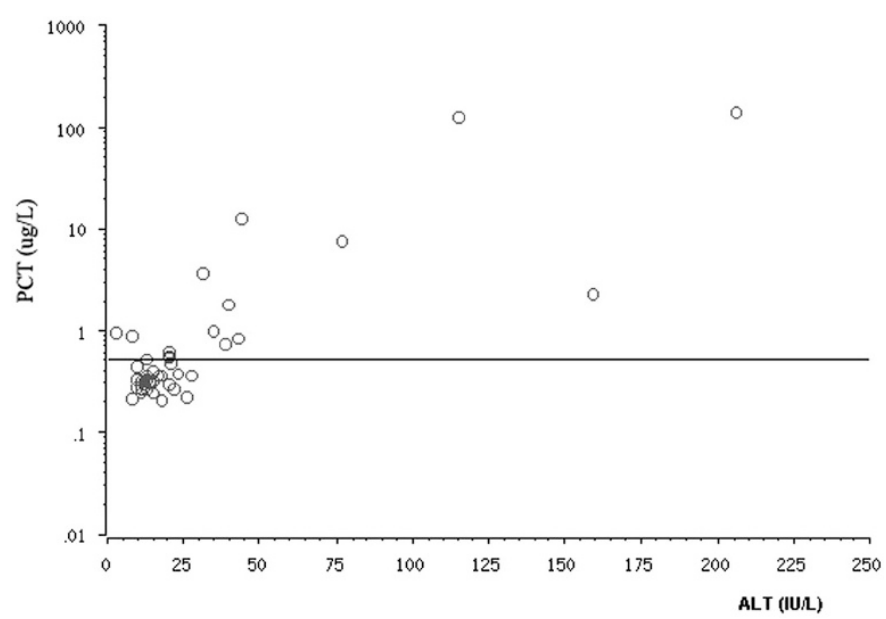

Figure 4. Circulating levels of serum PCT and ALT. Most children with serum PCT concentrations $>0.5 \mu \mathrm{g} / \mathrm{L}$ (-) also presented 2- to 5 -fold increased ALT levels. PCT was significantly correlated with ALT $\left(R^{2}=0.6\right.$; $p<0.001)$.

tor, growth-related oncogene- $\alpha$, macrophage inflammatory protein-1 $\beta$, macrophage chemotactic protein-1, epithelial-cell derived neutrophil activating peptide-78, transforming growth factor- $\beta 1$, sFas, and mannan-binding lectin $(18,21-24)$.

In light of earlier studies suggesting that freshly isolated human PBMC express PCT mRNA in response to stimulation with LPS (26), we treated undifferentiated (monocytic) and differentiated (macrophage-like) THP-1 cells with purified Stx 1 and/or LPS for 1-8 h. Using two separate primer sets in real-time PCR analyses, we did not detect PCT mRNA transcripts synthesized in response to the stimulants.

\section{DISCUSSION}

In this study, we found that children with D+ HUS presented with increased serum levels of PCT compared with those with an uncomplicated course of E. coli O157:H7 HC. Higher concentrations were also noted among children with $\mathrm{D}+$ HUS who required dialysis. Taken together, these results indicate that PCT is associated with severity of illness. We noted very high concentrations among four children with D + HUS, on the fifth or sixth day after the onset of enteric symptoms. Conversely, serial measurements of PCT in patients with $\mathrm{O} 157: \mathrm{H} 7 \mathrm{HC}$ were within the normal range throughout the first week of illness. The lack of serial measurements before and after the development of D+ HUS constitutes a major limitation of our study as it precludes to calculation of diagnostic predictive values. We acknowledge that few children with D+ HUS had blood samples drawn during the period of highest risk for the development of $\mathrm{D}+$ HUS, which is around 3-4 d after the onset of enteric symptoms $(27,28)$. In this regard, a slightly increased PCT level $(1.9 \mu \mathrm{g} / \mathrm{L})$ was noted $3 \mathrm{~d}$ after the onset of enteritis in one patient with uncomplicated O157:H7 HC.

The magnitude of increase in PCT concentrations noted among some children with D+ HUS was comparable to that found in two patients with Salmonella enteritis. Although STEC are noninvasive pathogens (2), these PCT concentrations were similar to values reported among children with septic shock $(29,30)$. Treatment of freshly isolated PBMC with LPS, TNF- $\alpha$, IL- $1 \beta$, or IL-6 has been reported to induce PCT at the mRNA and protein levels (26). PCT has been found within liver, kidneys, aorta, fat, ovaries, bladder, and adrenal glands of baboons treated with endotoxin $(11,12)$. The cellular origin of PCT within serum of children with D+ HUS is unclear. In this study, we found normal PCT levels among children with CRF on peritoneal dialysis. Slightly increased PCT concentrations have been noted in adults with chronic renal insufficiency (31), whether or not they required renal replacement therapy (32). In patients with advanced chronic renal disease, PCT may be augmented due to reduced renal elimination combined with an increased release of PCT by PBMC (32). Conversely, a comparable natural elimination rate of PCT has been noted in patients with normal or impaired renal function (33). Three studies in baboons or humans suggest that the liver constitutes a major source of PCT within blood (34-36). In this regard, we noted significant correlations between elevations in serum PCT and levels of LPSbinding protein or ALT. We acknowledge however that LPSbinding protein is also an acute phase reactant protein tht does not necessarily imply a biologic effect mediated by the lipid A component of endotoxin (25).

Using two separate sets of primers, we were unable to detect elevated levels of PCT mRNA from Stx-1 and/or LPS stimulated undifferentiated (monocytic) or differentiated (macrophage-like) THP-1 cells. This is in contrast to previous data by Harrison et al. $(9,20)$, who demonstrated under similar experimental conditions that these toxins, alone or in combination, induced the synthesis of TNF- $\alpha$, IL- $1 \beta$, and both $\mathrm{C}-\mathrm{X}-\mathrm{C}$ and $\mathrm{CC}$ chemokines. Intracellular PCT has been detected within peripheral blood monocytes stimulated with S. aureus (37). Oberhoffer et al. (26) reported increased expression of PCT mRNA and protein in unfractionated human PBMC stimulated with LPS, TNF- $\alpha$, IL-2, or IL-6. The discrepancy with our results may be explained by the fact that our experiments were performed using a lower dose of LPS $(0.2 \mu \mathrm{g} / \mathrm{mL}$ versus $10 \mu \mathrm{g} / \mathrm{mL})$ on a nonadherent monocytic cell line, or on adherent macrophage-like cells $4 \mathrm{~d}$ after differentiation. Indeed, Linscheid et al. (15) reported a transient elevation in PCT mRNA expression by human peripheral blood monocytes immediately after adherence to endothelial cells or plastic surfaces. Furthermore, expression of calcitonin or calcitonin gene-related peptide 1 was noted in adipose tissue biopsies but not in leukocytes isolated from patients with high serum levels of PCT $(15,38)$. In coculture experiments, adipocyte calcitonin mRNA expression was stimulated by $E$. coli-activated macrophages in which calcitonin mRNA was undetectable (15). Collectively, these data suggest that macrophage interaction with parenchymal cells stimulate PCT expression by nonmyeloid cells.

In this study, we showed that serum PCT levels are associated with severity of illness in childhood D+ HUS. However, it is unclear how PCT may be used for the diagnosis or management of children with STEC infections. We speculate that Stx, LPS, or other bacterial virulence factors may have induced cell activation and PCT secretion through complex mechanisms of cellular cross-talk that could not be reproduced 
by our experiments utilizing a single cell type. Further studies are needed to determine the role of PCT in the pathogenesis of thrombotic microangiopathy associated with childhood D + HUS.

Acknowledgments. The authors thank our research assistants, H. Brassard, A. Proietti, and R. Trahan, who collected blood specimens.

\section{REFERENCES}

1. Karmali MA, Petric M, Lim C, Fleming PC, Arbus GS, Lior H 1985 The association between idiopathic hemolytic uremic syndrome and infection by verotoxinproducing Escherichia coli. J Infect Dis 151:775-782

2. Proulx F, Seidman EG, Karpman D 2001 Pathogenesis of Shiga toxin-associated hemolytic uremic syndrome. Pediatr Res 50:163-171

3. Te Loo DM, van Hinsbergh VW, van den Heuvel LP, Monnens LA 2001 Detection of verocytotoxin bound to circulating polymorphonuclear leukocytes of patients with hemolytic uremic syndrome. J Am Soc Nephrol 12:800-806

4. te Loo DM, Monnens LA, van Der Velden TJ, Vermeer MA, Preyers F, Demacker PN, van Den Heuvel LP, van Hinsbergh VW 2000 Binding and transfer of verocytotoxin by polymorphonuclear leukocytes in hemolytic uremic syndrome. Blood 95:3396-3402

5. te Loo DM, Heuvelink AE, de Boer E, Nauta J, van der Walle J, Schroder C, van Hinsbergh VW, Chart H, van de Kar NC, van den Heuvel LP 2001 Vero cytotoxin binding to polymorphonuclear leukocytes among households with children with hemolytic uremic syndrome. J Infect Dis 184:446-450

6. Tazzari PL, Ricci F, Carnicelli D, Caprioli A, Tozzi AE, Rizzoni G, Conte R, Brigotti M 2004 Flow cytometry detection of Shiga toxins in the blood from children with hemolytic uremic syndrome. Cytometry B Clin Cytom 61:40-44

7. Uchida H, Kiyokawa N, Horie H, Fujimoto J, Takeda T 1999 The detection of Shiga toxins in the kidney of a patient with hemolytic uremic syndrome. Pediatr Res 45:133-137

8. Chaisri U, Nagata M, Kurazono H, Horie H, Tongtawe P, Hayashi H, Watanabe T, Tapchaisri P, Chongsa-nguan M, Chaicumpa W 2001 Localization of Shiga toxins of enterohaemorrhagic Escherichia coli in kidneys of paediatric and geriatric patients with fatal haemolytic uraemic syndrome. Microb Pathog 31:59-67

9. Harrison LM, van Haaften WC, Tesh VL 2004 Regulation of proinflammatory cytokine expression by Shiga toxin 1 and/or lipopolysaccharides in the human monocytic cell line THP-1. Infect Immun 72:2618-2627

10. Palermo MS, Alves Rosa MF, Van Rooijen N, Isturiz MA 1999 Depletion of liver and splenic macrophages reduces the lethality of Shiga toxin-2 in a mouse model. Clin Exp Immunol 116:462-467

11. Morgenthaler NG, Struck J, Chancerelle Y, Weglohner W, Agay D, Bohuon C, Suarez-Domenech V, Bergmann A, Muller B 2003 Production of procalcitonin (PCT) in non-thyroidal tissue after LPS injection. Horm Metab Res 35:290-295

12. Dandona P, Nix D, Wilson MF, Aljada A, Love J, Assicot M, Bohuon C 1994 Procalcitonin increase after endotoxin injection in normal subjects. J Clin Endocrinol Metab 79:1605-1608

13. Reinhart K, Karzai W, Meisner M 2000 Procalcitonin as a marker of the systemic inflammatory response to infection. Intensive Care Med 26:1193-1200

14. Brunkhorst FM, Heinz U, Forycki ZF 1998 Kinetics of procalcitonin in iatrogenic sepsis. Intensive Care Med 24:888-889

15. Linscheid P, Seboek D, Nylen E, Langer I, Schlatter M, Becker K, Keller U, Muller B 2003 In vitro and in vivo calcitonin I gene expression in parenchymal cells: a novel product of human adipose tissue. Endocrinology 144:5578-5584

16. Sabat R, Hoflich C, Docke WD, Oppert M, Kern F, Windrich B, Rosenberger C, Kaden J, Volk HD, Reinke P 2001 Massive elevation of procalcitonin plasma levels in the absence of infection in kidney transplant patients treated with pan-T-cell antibodies. Intensive Care Med 27:987-991

17. Eberhard OK, Langefeld I, Kuse ER, Brunkhorst FM, Kliem V, Schlitt HJ, Pichlmayr R, Koch KM, Brunkhorst R 1998 Procalcitonin in the early phase after renal transplantation-will it add to diagnostic accuracy? Clin Transplant 12:206-211
18. Proulx F, Toledano B, Phan V, Clermont MJ, Mariscalco MM, Seidman EG 2002 Circulating granulocyte colony-stimulating factor, $\mathrm{C}-\mathrm{X}-\mathrm{C}$, and $\mathrm{C}-\mathrm{C}$ chemokines in children with Escherichia coli $\mathrm{O} 157: \mathrm{H} 7$ associated hemolytic uremic syndrome. Pediatr Res 52:928-934

19. Nicholson J, Pesce M 2004 Reference ranges for laboratory tests and procedures. In Behrman R, Kliegman R, Jenson H (eds) Nelson Textbook of Pediatrics. Saunders, Philadelphia pp 2396-2426

20. Harrison LM, van den Hoogen C, van Haaften WC, Tesh VL 2005 Chemokine expression in the monocytic cell line THP-1 in response to purified shiga toxin 1 and/or lipopolysaccharides. Infect Immun 73:403-412

21. Proulx F, Turgeon JP, Litalien C, Mariscalco MM, Robitaille P, Seidman E 1998 Inflammatory mediators in Escherichia coli O157:H7 hemorrhagic colitis and hemolytic-uremic syndrome. Pediatr Infect Dis J 17:899-904

22. Proulx F, Litalien C, Turgeon JP, Mariscalco MM, Seidman E 2000 Circulating levels of transforming growth factor-betal and lymphokines among children with hemolytic uremic syndrome. Am J Kidney Dis 35:29-34

23. Masri C, Proulx F, Toledano B, Clermont MJ, Mariscalco MM, Seidman EG, Carcillo J 2000 Soluble Fas and soluble Fas-ligand in children with Escherichia coli O157:H7-associated hemolytic uremic syndrome. Am J Kidney Dis 36:687-694

24. Litalien C, Proulx F, Mariscalco MM, Robitaille P, Turgeon JP, Orrbine E, Rowe PC, McLaine PN, Seidman E 1999 Circulating inflammatory cytokine levels in hemolytic uremic syndrome. Pediatr Nephrol 13:840-845

25. Proulx F, Seidman E, Mariscalco MM, Lee K, Caroll S 1999 Increased circulating levels of lipopolysaccharide binding protein in children with Escherichia coli O157:H7 hemorrhagic colitis and hemolytic uremic syndrome. Clin Diagn Lab Immunol 6:773

26. Oberhoffer M, Stonans I, Russwurm S, Stonane E, Vogelsang H, Junker U, Jager L, Reinhart K 1999 Procalcitonin expression in human peripheral blood mononuclear cells and its modulation by lipopolysaccharides and sepsis-related cytokines in vitro. J Lab Clin Med 134:49-55

27. Buteau C, Proulx F, Chaibou M, Raymond D, Clermont MJ, Mariscalco MM, Lebel MH, Seidman E 2000 Leukocytosis in children with Escherichia coli O157:H7 enteritis developing the hemolytic-uremic syndrome. Pediatr Infect Dis J 19:642_ 647

28. Bell BP, Griffin PM, Lozano P, Christie DL, Kobayashi JM, Tarr PI 1997 Predictors of hemolytic uremic syndrome in children during a large outbreak of Escherichia coli O157:H7 infections. Pediatrics 100:E12

29. Han YY, Doughty LA, Kofos D, Sasser H, Carcillo JA 2003 Procalcitonin is persistently increased among children with poor outcome from bacterial sepsis. Pediatr Crit Care Med 4:21-25

30. Carrol ED, Newland P, Thomson AP, Hart CA 2005 Prognostic value of procalcitonin in children with meningococcal sepsis. Crit Care Med 33:224-225

31. Steinbach G, Bolke E, Grunert A, Storck M, Orth K 2004 Procalcitonin in patients with acute and chronic renal insufficiency. Wien Klin Wochenschr 116:849-853

32. Herget-Rosenthal S, Klein T, Marggraf G, Hirsch T, Jakob HG, Philipp T, Kribben A 2005 Modulation and source of procalcitonin in reduced renal function and renal replacement therapy. Scand J Immunol 61:180-186

33. Meisner M, Lohs T, Huettemann E, Schmidt J, Hueller M, Reinhart K 2001 The plasma elimination rate and urinary secretion of procalcitonin in patients with normal and impaired renal function. Eur J Anaesthesiol 18:79-87

34. Meisner M, Muller V, Khakpour Z, Toegel E, Redl H 2003 Induction of procalcitonin and proinflammatory cytokines in an anhepatic baboon endotoxin shock model. Shock 19:187-190

35. Kretzschmar M, Kruger A, Schirrmeister W 2001 Procalcitonin following elective partial liver resection-origin from the liver? Acta Anaesthesiol Scand 45:11621167

36. Fazakas J, Gondos T, Varga M, Sarvary E, Horovitz P, Perner F 2003 Analysis of systemic and regional procalcitonin serum levels during liver transplantation. Transpl Int 16:465-470

37. Balog A, Ocsovszki I, Mandi Y 2002 Flow cytometric analysis of procalcitonin expression in human monocytes and granulocytes. Immunol Lett 84:199-203

38. Linscheid P, Seboek D, Schaer DJ, Zulewski H, Keller U, Muller B 2004 Expression and secretion of procalcitonin and calcitonin gene-related peptide by adherent monocytes and by macrophage-activated adipocytes. Crit Care Med $32: 1715-1721$ 